\section{Effect of visual impairment upon oral health care: a review}

\author{
E. K. Mahoney, ${ }^{1}$ N. Kumar ${ }^{2}$ and S. R. Porter ${ }^{3}$
}

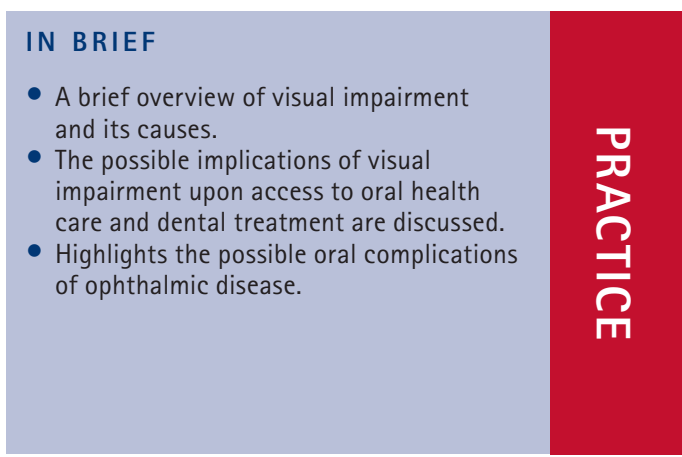

The incidence of visual impairment is increasing globally and in the United Kingdom due to local and systemic disease, medical advances, and the increasing age of population groups. Despite there being a large number of people resident in the UK with a visual impairment, there is little information available regarding the dental health care and needs of such individuals. As reported in other groups of patients with special needs, many individuals with a visual impairment may only seek oral health care when a problem arises, such as pain. Visual impairment may have a negative effect upon oral hygiene with many blind and partially sighted individuals having worse oral hygiene than sighted peers.

This review article was undertaken to examine the literature relating to visual impairment, oral health and dental care. This article will discuss the dental aspects of visual impairment, its implications for obtaining dental care, associated oral conditions and medical complications.

\section{INTRODUCTION}

Globally in 1997 the WHO estimated that there were 45 million people who were blind, almost $60 \%$ of whom were aged more than 60 years. ${ }^{1}$ The most common causes of blindness globally are cataract (43\%) and ocular disease secondary to diabetes mellitus (24\%). ${ }^{1-2}$ In the UK there are approximately two million people with a severe sight problem, the majority of whom are also over 60 years of age. This is likely to increase with medical advances, increasing life expectancy and the rising number of people affected by diabetes mellitus. ${ }^{3}$ In developed countries like the UK the most common cause of visual impairment is age-related macular degeneration. ${ }^{4}$ Only $8 \%$ of people have a congenital visual impairment with the rest developing a visual impairment through local or systemic disease, accidents or age related degeneration. ${ }^{3,5-6}$ It is estimated that other disabilities and

$1-3^{*}$ Oral Medicine and Special Needs, UCL Eastman Dental Institute, 256 Gray's Inn Road, London WC1X 8LD

${ }^{*}$ Correspondence to: Professor Stephen R. Porter Email:s.porter@eastman.ucl.ac.uk

\section{Refereed Paper}

Accepted 25 September 2007

DOI: $10.1038 /$ bdj.2008.2

${ }^{\circledR}$ British Dental Journal 2008; 204: 63-67 health problems occur in two thirds of those with a visual impairment. Some of the causes of visual impairment are indicated in Table 1.

\section{DENTAL CARE FOR INDIVIDUALS WITH A VISUAL IMPAIRMENT}

The provision of oral health care to adults with a visual disability differs in physical access to surgeries, access to information as well as associated disabilities or medical conditions that affect dental care, such as diabetes mellitus or cardiac disease. With the full implementation of the Disability Discrimination Act $1995^{7}$ there is a need to ensure that all barriers to dental care for this group of individuals are removed to ensure equal access for all.

\section{Access to dental services}

Many individuals with a visual disability receive dental care in the General Dental Service and those with complicating medical conditions may be seen in community and hospital dental services. Sighted individuals often find dental care through directories such as the yellow pages and advertising, but for some visually impaired people this may not be possible. However, with the advent of NHS direct telephone advice service and telephone directory services, individuals should have improved access to information on local dental services. Individuals with a visual impairment may prefer to attend the same practitioner over many years as routes can be learnt and building/surgery layouts become familiar.

Physical access may be the first barrier to accessing dental care for individuals with a visual impairment. To improve access to dental services simple measures such as keeping passages clear, ensuring areas are well lit, door frames and handles are well defined, having high backed chairs with arms, placing large print signs in areas of danger, and placing handrails by stairs can be used. ${ }^{8}$ In addition, tactile maps, paths, Braille signs and use of contrasting colours are helpful. ${ }^{9}$

The first person a patient may come into contact with is the receptionist and it is important that they introduce themselves. It may be appropriate for the receptionist to offer to lead the patient to a chair, taking care to avoid any obstacles and explain the surroundings. ${ }^{10-12}$

Communication in the dental setting takes four broad forms: verbal, non-verbal, affective/paralinguistic and written. ${ }^{13-14}$ Hence it is not only what dental staff may say but the way they say it, the 


\section{Table 1 Causes of visual impairment}

Primary ocular disease

Acquired:

Age-related macular degeneration

Cararacts

Glaucoma

Hemianopia

High degree myopia

Nystagmus

Retinal vein occlusion (thrombosis)

Retinopathy of prematurity

Uveitis

\section{Congenital:}

Aniridia

Best's Disease

Charles Bonnet syndrome

Coats Disease

Colomboma

Congenital cataracts

Corneal dystrophy

Ehlers-Danlos syndrome

Genetic eye disease

High degree myopia

Intrauterine infections (CMV, Rubella, Syphilis)

Lacrimo-auricular-dento-digital syndrome

Laurence-Moon-Biedl syndrome

Marfans syndrome

Nystagmus

Oculo-facio-cardio-dental syndrome

Retinitis pigmentosa

Rieger syndrome

Treacher-Collins syndrome

Various inborn errors of metabolism

Zimmerman-Laband syndrome
Secondary ocular disease

Acquired:

Acromegaly

Behcets

Corneal graft

Diabetes related ocular disease (retinopathy, retinitis proliferans)

Dry eye (Sjorgrens syndrome)

Malignant hypertension

Mucous membrane pemphigoid

Multiple sclerosis (retrobulbar neuritis)

Muscular dystrophy

Reiter's syndrome

Steven-Johnson syndrome

Temporal arteritis / giant cell arteritis

Thyroid eye disease

Tumours:

Basal cell carcinoma

Melanoma

Metastases

Retinoblastoma

Infections:

CMV

Herpes simplex / zoster

Toxoplasmosis

Trachoma

Drugs:

Methanol

Phenothiazines

Quinine

Trauma:

Chemical trauma

Damage / loss of eye

Detached retina

Foreign body

Posterior vitreous detachment tone of voice used, their facial expression, behaviour and body language which all impact on communication. Patients who have a visual impairment may not pick up on certain non-verbal aspects and may be disadvantaged. With respect to written information used in dental services few provide large print/ Braille appointment cards or information sheets. ${ }^{8}$ One study found that, of the practices studied, 21\% produced large print leaflets, 15\% produced large print appointment cards and none produced information on audiotape. ${ }^{15}$

\section{Dental treatment}

It is vital to establish the degree of visual impairment so that information and treatment can be tailored accordingly. For example, some individuals are acutely sensitive to the operative light and thus it may be appropriate to provide dark safety glasses, as opposed to clear ones.

Dental treatment can be invasive and perceivably threatening and a visual impairment may make this more so, hence it may be appropriate to commence treatment with short appointments until the patient is accustomed to the dental staff and a rapport is established..$^{10-12}$ Schnuth ${ }^{16}$ indicated that fear and apprehension might be reduced by the encouragement of questioning by the patient. It may also be useful to allow patients to touch instruments and to explain their action as some patients rely on senses other than sight to mentally visualise objects. A clear ongoing description on what they will feel, hear, taste and smell is important to ensure the patient is not surprised by an unexpected feeling, sound or taste. Movements should be explained and then carried out in a slow and deliberate manner. ${ }^{10-12}$ A considerable proportion of adults with a visual impairment also have hearing loss which may require further modification to the provision of dental health care. ${ }^{17-18}$ As in other groups of patients with special needs, many individuals with a visual impairment may only seek oral health care when a problem arises such as pain. This is especially true of the elderly, up to $80 \%$ of whom may not aware that it is advisable to have regular dental examinations. ${ }^{19-20}$

\section{Medical complications of visual impairment relevant to dentistry}

Some causes of visual impairment may be associated with other medical problems, such as cardiac defects or systemic disease (eg diabetes), which are more likely to affect dental care than the visual impairment. However, some causes of visual impairment do impact on dental care, ie diazepam and atropine need to be avoided for patients with glaucoma. ${ }^{20-21}$ The provision of dental care for individuals with compromising medical conditions is adequately dealt with elsewhere and will not be discussed here. ${ }^{20-21}$

The medical conditions and disabilities most commonly associated with visual impairment ${ }^{9}$ are listed below and reflect the older age of visually impaired persons:

$\begin{array}{ll}\text { Hearing impairment } & 34 \% \\ \text { Arthritis } & 25 \% \\ \text { Heart condition } & 18 \% \\ \text { Mobility problems } & 14 \% \\ \text { Diabetes } & 9 \%\end{array}$

More of the general medical complications of ophthalmic disease are summarised in Table 2.

\section{Periodontal disease}

Advice on oral hygiene instruction should be adapted to reflect the individual's level of impairment. This may range from large bold text to Braille and audio information. There may also be a need to adapt oral hygiene instruction methods with the use of models and other aids. Studies of relevance have shown that 
Table 2 Oral and dental implications of some ophthalmic disorders

\begin{tabular}{|c|c|c|c|}
\hline Disease/Syndrome & Ocular defect & General medical features & Oral/dental anomalies \\
\hline \multicolumn{4}{|l|}{ Congenital: } \\
\hline Congenital syphilis & Uveitis & $\begin{array}{l}\text { Deafness, infection risk before } 2 \text { years } \\
\text { of age, cardiovascular and neurological } \\
\text { complications }\end{array}$ & $\begin{array}{l}\text { Hutchinson's incisors, Moon's molars, } \\
\text { possible micrognathia }\end{array}$ \\
\hline Cross syndrome & Microophthalmia, cloudy cornea & Learning disability & Gingival enlargement \\
\hline Ehlers-Danlos syndrome & Fragile cornea/sclera, early sight loss & $\begin{array}{l}\text { Cardiovascular and respiratory anoma- } \\
\text { lies, possible platelet defects }\end{array}$ & $\begin{array}{l}\text { Periodontal disease (rare), microdon- } \\
\text { tia, root morphology anomalies, pulp } \\
\text { stones }\end{array}$ \\
\hline $\begin{array}{l}\text { Lacrimo-auriculo-dento-digital } \\
\text { syndrome }\end{array}$ & Hypoplasia/aplasia of lacrimal puncta & & $\begin{array}{l}\text { Microdontia, hypodontia, dark/grey } \\
\text { thin enamel, midface hypoplasia }\end{array}$ \\
\hline Marfan's syndrome & Dislocated lens, retinal detachment & Cardiac and respiratory anomalies & High arched palate, TMJ anomalies \\
\hline Oculo-facio-cardio-dental syndrome & Congenital cataract, micro-ophthalmia & Renal impairment, hearing impairment & $\begin{array}{l}\text { Radiomegalic canines, delayed erup- } \\
\text { tion, open apices, malocclusions }\end{array}$ \\
\hline Patau's syndrome (Trisomy 13) & Microphthalmia, anophthalmia & Cardiac defects, polydactaly & $\begin{array}{l}\text { Microcephaly, clefts, malocclusion, } \\
\text { hypodontia, ectopic teeth }\end{array}$ \\
\hline Rieger syndrome & $\begin{array}{l}\text { Hypoplasia of iris, corneal/lens/ } \\
\text { Pupilary defects }\end{array}$ & Hepatosplenomegaly & $\begin{array}{l}\text { Hypodontia, maxillary/mandibular } \\
\text { hypoplasia, taurodontism }\end{array}$ \\
\hline Riley Day syndrome & Corneal ulceration, early sight loss & $\begin{array}{l}\text { Hypotension, pyrexia, dysphagia, } \\
\text { breath holding, kyphoscloiosis }\end{array}$ & $\begin{array}{l}\text { Crowding, early tooth loss, bruxism, } \\
\text { tooth surface loss, traumatic ulcera- } \\
\text { tion, hypersalivation, reduced pain } \\
\text { stimuli }\end{array}$ \\
\hline Rutherford syndrome & Corneal opacity & Learning disability, aggression & $\begin{array}{l}\text { Gingival enlargement, delayed erup- } \\
\text { tion, dentigerous cyst }\end{array}$ \\
\hline Treacher Collins syndrome & Colombomas & $\begin{array}{l}\text { Cardiac anomalies, hearing loss, } \\
\text { increased risk of oesophageal carci- } \\
\text { noma }\end{array}$ & $\begin{array}{l}\text { Malar and mandibular hypoplasia, } \\
\text { clefts, malocclusion, spacing, ectopic } \\
\text { and hypoplastic teeth, microstomia, } \\
\text { blind oral fistulas }\end{array}$ \\
\hline Turner's syndrome & $\begin{array}{l}\text { Ptosis, striabismus, amblyopia, } \\
\text { cataracts }\end{array}$ & $\begin{array}{l}\text { Scoliosis, hearing loss, hypertension, } \\
\text { cardiac defects/murmurs }\end{array}$ & $\begin{array}{l}\text { Retrognathia, reduced crown height } \\
\text { and root length, decreased enamel } \\
\text { thickness }\end{array}$ \\
\hline $\begin{array}{l}\text { Zimmerman-Laband syndrome } \\
\text { Other }\end{array}$ & Retinitis pigmentosa, cataracts & VSD, cardiomegaly, syndactyly & Gingival enlargement, delayed eruption \\
\hline \multicolumn{4}{|l|}{ Acquired: } \\
\hline Diabetes mellitus & Retinopathy, blindness & $\begin{array}{l}\text { Nephropathy, neuropathy, poor wound } \\
\text { healing, infection risk, hypertension, } \\
\text { ischaemic heart disease, cerebrovascu- } \\
\text { lar disease }\end{array}$ & $\begin{array}{l}\text { Periodontal disease, possible candidal } \\
\text { infection, xerostomia, lichen planus }\end{array}$ \\
\hline Herpes Simplex/Zoster viral infection & Ocular infection & Cross infection risk & \\
\hline Hypertension & Retinopathy, retinal haemorrhages & $\begin{array}{l}\text { Ischaemic heart disease, peripheral } \\
\text { vascular disease, cerebrovascular } \\
\text { disease, renal failure }\end{array}$ & $\begin{array}{l}\text { Drug-related xerostomia, lichen } \\
\text { planus, burning mouth, loss of taste, } \\
\text { gingival enlargement }\end{array}$ \\
\hline $\begin{array}{l}\text { Mucous membrane pemphigoid, } \\
\text { pemphigus vulgaris, Steven-Johnson } \\
\text { syndrome, Behcet's disease }\end{array}$ & $\begin{array}{l}\text { Corneal ulceration (all) } \\
\text { Symblepharon (pemphigus), others }\end{array}$ & $\begin{array}{l}\text { Corticosteroid therapy and other auto- } \\
\text { immune diseases may complicate care }\end{array}$ & $\begin{array}{l}\text { All may cause various types of oral } \\
\text { ulceration, pemphigoid may cause } \\
\text { mucosal scarring }\end{array}$ \\
\hline $\begin{array}{l}\text { Sjogren's syndrome } \\
\text { Others }\end{array}$ & Corneal ulceration & $\begin{array}{l}\text { Rheumatoid arthritis, anaemia, leuco- } \\
\text { penia, other auto-immune disorders }\end{array}$ & $\begin{array}{l}\text { Xerostomia, burning mouth, candidal } \\
\text { infection, sialadenitis, angular cheilitis, } \\
\text { liability to MALT Iymphoma }\end{array}$ \\
\hline
\end{tabular}


individuals with a visual impairment are used to relying on verbal instructions and following them carefully and respond well to simple information which is adequately explained. ${ }^{19}$

Visual impairment can have a negative effect upon oral hygiene, some individuals having poorer oral hygiene than sighted peers. ${ }^{22-23}$ There may also be an increase in periodontal disease with higher levels of calculus and debris than those who lack a visual impairment. ${ }^{22-23}$ Several studies have examined oral hygiene advice for people who are blind or visually impaired (mainly children). These have hinged upon the use of good verbal instruction and tactile aids to improve tooth brushing methods. ${ }^{24-26}$ 0'Donnell and Crosswaite ${ }^{26}$ found that children who were blind were very adept at converting oral instructions into manual oral hygiene practices. This confirms that given adequate verbal instruction individuals with a visual impairment can have the same levels of oral health as their sighted peers. Adequate oral hygiene instruction can have a positive impact on oral hygiene, periodontal status and maintain or improve self esteem. ${ }^{16,19,27}$

\section{Dental caries}

There appear to be no published data available on dental caries in adults who are blind or partially sighted. A study of children suggested that caries load is not affected by visual impairment. ${ }^{22} \mathrm{~A}$ more recent study has shown a reduced number of decayed, missing or filled teeth (DMFT) in children who are visually impaired compared to sighted controls, ${ }^{28}$ whereas others reported that DMFT scores were higher in a population of children who were blind when compared to sighted peers. ${ }^{12}$ However, there is a positive association between some causes of ocular disease and dental caries, ie Sjögren's syndrome. ${ }^{29}$

\section{Dental anomalies}

It has previously been suggested that children who are visually impaired or blind have a liability to traumatic injuries of the teeth and the soft tissues of the mouth. ${ }^{30}$ A study of children with impaired vision and hearing found that children with a visual impairment had a slightly higher incidence of incisal trauma than their sighted peers $(9 \%$ and $6.7 \%$ respectively). ${ }^{31}$ Others found no increased incidence of enamel fracture between the two groups of young adults. $^{22}$

Dental anomalies secondary to congenital disease giving rise to sight loss may occur, eg enamel hypoplasia (Table 2). One report suggested an association between coloboma of the iris, hypodontia and amelogenesis imperfecta. ${ }^{32}$ However, there appear to be no published reports of the rate and nature of dental anomalies associated with congenital sight loss.

It has also been suggested that occlusal wear may be increased in some individuals with a visual impairment, as a consequence of bruxism, ${ }^{30}$ but the exact mechanism by which this occurs is unclear. Others have reported an association between ocular convergence and functional mandibular deviation. ${ }^{33}$ Bruxism is also often associated with developmental delay and learning disability. ${ }^{34}$ There is also an association between bruxism and familial dysautonomia (Riley-Day syndrome), an extremely rare disorder characterised by associated ocular involvement; there is reduced pain perception. ${ }^{35-37}$

\section{Orthodontic treatment}

Al-Sarheed and co-workers ${ }^{38}$ found that children with a visual disability had a higher aesthetic orthodontic need than a sighted control population. It was noted that the parents felt their children were unconcerned about their appearance, yet in contrast, it was found that almost two thirds of children with a visual impairment wished orthodontic treatment.

\section{Soft tissue lesions}

Mucosal lesions may arise in individuals with impaired vision possibly as a consequence of bruxism and lip/cheek biting, ${ }^{30}$ but there are no data to suggest that oral mucosal disease is notably increased in the visually impaired. An association has been highlighted between some congenital ocular defects and gingival fibromatosis/enlargement. ${ }^{39}$ Impaired vision may prevent detection of asymptomatic oral mucosal disease, ${ }^{19-20}$ eg malignancy, yet without good data this cannot be proved.

\section{SUMMARY}

The prevalence of visual impairment is increasing. This may be due in part to the increase in the average life expectancy of the population, improvements in medical science and higher levels of diabetes mellitus. Visual impairment may impact on access to dental care and oral health information. Associated systemic disease may complicate dental management. There is a paucity of information available on dental care for visually impaired adults and little information to help direct future health plans. The currently available data concerning visual impairment and dental care provided are out of date and provide conflicting advice. Clarification is required to enable effective and timely dental care service provision.

\section{FUTURE RECOMMENDATIONS}

As there are few data available on the oral health of individuals with a visual impairment more relevant research is needed to make any authoritative conclusions.

1. World Health Organization. World Health Report 1998. 2004. http://www.who.int/whr/1998/en/ index.html (accessed 6th November 2007).

2. Thylefors B, Negrel A D, Pararajasegaram R, Dadzie K Y. Global data on blindness. Bulletin of the World Health Organization 1995; 73: 115-121.

3. Royal National Institute for the Blind, 2004 www.rnib.org.uk. (accessed 6th November 2007).

4. Apte R S, Scheufele T A, Blomquist P H. Etiology of Blindness in an Urban Community Hospital Setting. Ophthalmology 2001; 108: 693-696.

5. Royal National Institute for the Blind. See change. London: Royal National Institute for the Blind, 2003.

6. Rukanko S L, Fellman V, Laatikainen L. Visual impairment in children born prematurely from 1972 through 1989. Ophthalmology 2003; 110: 1639-1645.

7. Disability Discrimination Act. London: HMSO, 1995. www.disability.gov.uk.

8. Edwards D M, Merry A J, Pealing R. Disability Part 3: Improving access to dental practices in Merseyside. Br Dent J 2002; 193: 317-319.

9. Royal National Institute for the Blind. III Informed Campaign Report 7. London: Royal National Institute for the Blind, 1995.

10. Davis R L. The blind dental patient. I/I Dent J 1965; 34: 18-21.

11. Lebowitz E J. An introduction to dentistry for the blind. Dent Clin North Am 1974; 18: 651-659.

12. Dios P D. Oral care in the blind and visually impaired. In Porter S R, Scully C. Oral health care for those with HIV Infection and other special needs. pp 219-221. Northwood Science Reviews, 1995.

13. Freeman R. Communication, body language and dental anxiety. Dent Update 1992; Sep: 307-309.

14. Newton J T. Dentist/patient communication: a review. Dent Update 1995; Apr: 118-122.

15. Edwards D M, Merry A J. Disability Part 2: Access to dental services for disabled people. A questionnaire survey of dental practices in Merseyside. Br Dent J 2002; 193: 253-255.

16. Schnuth M L. Dental health education for the blind. Dent Hyg 1977; 51: 499-501. 
17. Schell C L, Diehl R L, Hilmes A E, Kubilis et al. An association between dentate status and hearing acuity. Spec Care Dent 1999; 19: 208-213.

18. Lawrence H P, Garcia R I, Essick G K, Hawkins R et al. A longitudinal study of the association between tooth loss and age related hearing loss. Spec Care Dent 2001; 21: 129-140.

19. Schembri A, Fiske J. The implications of visual impairment in an elderly population in recognizing oral disease and maintaining oral health. Spec Care Dent 2001; 21: 222-226.

20. Scully C, Diz Dios P, Kumar N. Special care in dentistry - handbook of oral healthcare. pp 1-512. Churchill Livingstone, London, 2006.

21. Scully C, Cawson R A. Medical problems in dentistry, $4^{\text {th }}$ ed. pp 178-180, 314-316, 351-354, 558-560. Oxford: Wright, 1998

22. Greeley C B, Goldstein P A, Forrester D J. Oral manifestations in a group of blind students. J Dent Child 1976; 26: 39-41.

23. Anaise $J Z$. Periodontal disease and oral hygiene in a group of blind and sighted Israeli teenagers 14-17 years of age. Community Dent Oral Epidemiol 1979; 7: 353-356.

24. Winstanley M L. A synopsis of the project to evaluate the use of Braille text and tactile aids when teaching dental health to blind children. Br Dent Surg Assist 1983; Mar/Apr: 20-23.

25. Cohen $S$, Sarnat H, Shalgi G. The role of instruction and a brushing device on the oral hygiene of blind children. Clin Prev Dent 1991; 13: 8-12.

26. O'Donnell D, Crosswaite M A. Dental health education for the visually impaired child. J R Soc Health 1990; 2: 60-61.

27. Ajwani S, Ainamo A. Periodontal conditions among the elderly: five-year longitudinal study. Spec Care Dent 2001; 21: 45-51.

28. Shyama M, Al-Mutawa S A, Morris R E, Sugathan $T$, Honkala E. Dental caries experience of disabled children and young adults in Kuwait. Community
Dent Health 2001; 18: 181-186.

29. Koseki M, Maki Y, Matsukubo T, Ohashi Y, Tsubota K. Salivary flow and its relationship to oral signs and symptoms in patients with dry eyes. Oral Dis 2004; 10: 75-80.

30. Rapp R, Kanar H L, Nagler B. Pedodontic care for the deaf and blind. Dent Clin North Am 1966; 10: $21-34$.

31. Al-Sareed M, Bedi R, Hunt N P. Traumatised permanent teeth in 11-16-year-old Saudi Arabian children with a sensory impairment attending special schools. Dent Traumatol 2003; 19: 123-125.

32. Atasu M, Eryilmaz A, Genc A, Ozcan M, Ozbayrak $S$. Congenital hypodontia of maxillary lateral incisors in association with coloboma of the iris and hypomaturation type of amelogenesis imperfecta in a large kindred. J Clin Pediatr Dent 1997; 21: 341-355.

33. Monaco A, Streni O, Marci M C, Sabetti L, Marzo G, Giannoni M. Relationship between mandibular deviation and ocular convergence. J Clin Pediatr Dent 2004; 28: 135-138.

34. Tesini D A, Fenton S J. Oral health needs of persons with physical or mental disabilities. Dent Clin North Am 1994; 38: 483-497.

35. Mass E, Sarnet H, Ram D, Gadoth N. Dental and oral findings in patients with familial dysautonomia. Oral Surg Oral Med Oral Pathol 1992 74: 305-311.

36. Nussbaum B L. Dental management of a child with familial dysautonomia. J Dent Child 1986: 53: 293-295.

37. Thompson B H, Hartwell G R, Ekvall W M, Koudelka $B$ M. Endodontic management of a patient with familial dysautonomia. J Endod 1986; 12: 170-173.

38. Al-Sareed M, Bedi R, Hunt N P. The views and attitudes of parents of children with a sensory impairment towards orthodontic care. Eur J Orthod 2004; 26: 87-91.

39. Shah N, Gupta Y K, Ghose S. Zimmerman-Laband syndrome with bilateral developmental cataract - a new association? Int J Paediatr Dent 2004; 14: 78-85.

40. American Foundation for the Blind. Glossary of Eye Conditions. 2004. www.afb.org/Section. asp? Document $\mid \mathrm{D}=2139$ \&tMode $=$ Print

41. Batterbury M, Bowling B. Ophthalmology: an illustrated colour text. pp 2-15. London: Churchill Livingstone, 2004.

42. Kawamoto T, Motohashi N, Ohyama K. A case of oculo-facio-cardio-dental syndrome with integrated orthodontic-prosthodontic treatment. Cleft Palate Craniofac J 2004; 41: 84-94.

43. Kumar $\mathrm{P}$, Clark M. Clinical medicine, $5^{\text {th }}$ ed. pp 125 127, 172-180, 821, 1069-1102. London: Saunders, 2002.

44. Kuru B, McCullough M J, Yilmaz S, Porter S R. Clinical and microbiological studies of periodontal disease in Sjögren's syndrome patients. J Clin Periodontol 2002; 29: 92-102.

45. Barthelemy I, Samuels L, Schendel S. Oculo-faciocardio-dental syndrome: two new cases. J Oral Maxillofac Surg 2001; 59: 921-928.

46. Scully C. Handbook of oral disease. Diagnosis and management, revised ed. pp 85-88, 203-212, 320 325. London: Martin Dunitz, 2001.

47. Dimitrakopoulos J, Voyatzis N, Katopodi T. Rieger syndrome: a case report. J Oral Maxillofac Surg 1997; 55: 517-521.

48. Lilly J P, Spivey J D, Fotos P G. Benign mucous membrane pemphigoid with advanced periodontal involvement: diagnosis and therapy. J Periodontol 1995; 66: 737-741.

49. Toumba K J, Gutteridge D L. Lacrimo-auriculodento-digital syndrome: a literature review and case reports. Quintessence Int 1995; 26: 829-839.

50. Scully C, Porter S. Orofacial diseases: update for the dental clinical team: 2. Ulcers, erosions and other causes of sore mouth Part I. Dent Update 1998; 25: 478-484. 